\title{
Sunflower subjected to boron doses in the semi-arid from Northern Minas Gerais, Brazil
}

\author{
Raniell Inácio Leandro ${ }^{1} \oplus$, Claubert Wagner Guimarães de Menezes ${ }^{1} \oplus$, Aroldo Gomes Filho' ${ }^{1}$, \\ Paloma Leite Gomes ${ }^{1} \odot$, Dilermando Dourado Pacheco ${ }^{1} \odot$, Claudio Guilherme Portela de Carvalhoº
1 Instituto Federal do Norte de Minas Gerais, Campus Januária, Januária, MG, Brasil. E-mail: raniellinacio@gmail.com; claubertmenezes@yahoo.com.br; aroldofilho@hotmail.com; pallomagomes2010@hotmail.com; ddpacheco.agro@gmail.com
${ }^{2}$ Embrapa Soja, Londrina, PR, Brasil. E-mail: portela.carvalho@embrapa.br

ABSTRACT: The sunflower [Helianthus annuus L. (Asteraceae)] is an annual dicotyledon, and its seeds can be used for animal and human consumption, for extracting fixed oil and for producing biodiesel. This plant is sensitive to boron (B) deficiency, with the scarcity of this micronutrient leading to lesions in the leaves and stem of the sunflower, causing the collapse of the capitulum and decreased photosynthesis. The objective of this study was to evaluate the development and the productive response of the sunflower genotypes BRS 321 and BRS 323, subjected to four doses of B $\left(0,1,2\right.$ and $\left.4 \mathrm{~kg} \mathrm{ha}^{-1}\right)$. The experimental design was in randomized blocks with three replicates and 8 treatments. Plant height, plant diameter , capitulum diameter, number of leaves, weight of 1000 achenes, grain yield, fixed oil content and oil yield were all evaluated. Doses greater than $1 \mathrm{~kg} \mathrm{ha}^{-1}$ of $B$ caused toxicity symptoms in the vegetative phase in the BRS 321 genotype, however, the $4 \mathrm{~kg} \mathrm{ha}^{-1}$ dose of B promoted productive gains to this same genotype. The BRS 323 genotype was more productive in grain and fixed oil than the BRS 321 genotype, regardless of the B doses. In order to avoid phytotoxicity, applications of B to the BRS 321 genotype are recommended.

\section{Cultivo do girassol submetido a doses de boro no semiárido do Norte de Minas Gerais, Brasil}

RESUMO: O girassol [Helianthus annuus L. (Asteraceae)] é uma planta utilizada para o consumo animal e humano, na extração de óleo fixo e para a produção de biodiesel. A planta é sensível a deficiência de boro (B), e a escassez desse micronutriente ocasiona lesões nas folhas e caule do girassol, causando o tombamento do capítulo e diminuição da fotossíntese. 0 objetivo desse trabalho foi avaliar o desenvolvimento e a resposta produtiva dos genótipos de girassol BRS 321 e BRS 323, submetidos a quatro doses de $B\left(0,1,2\right.$ e $\left.4 \mathrm{~kg} \mathrm{ha}^{-1}\right)$. 0 delineamento experimental foi em blocos casualizados em esquema fatorial $4 \times 2$ (dose de boro x genótipos de girassol), com três repetições e 8 tratamentos. Altura da planta, diâmetro do capítulo, diâmetro do caule, número de folhas, massa de mil aquênios, produtividade de grãos, teor de óleo fixo e produtividade de óleo foram avaliados. As doses superiores a $1 \mathrm{~kg} \mathrm{ha}^{-1}$ de B causaram sintomas de toxidez na fase vegetativa para o genótipo BRS 321, porém, a dose de $4 \mathrm{~kg} \mathrm{ha}^{-1}$ de $\mathrm{B}$ rendeu ganhos produtivos ao mesmo genótipo. 0 genótipo BRS 323 foi mais produtivo que o genótipo BRS 321 em grãos e óleo fixo, independente das doses de B. Recomenda-se aplicações parceladas de B para 0 genótipo BRS 321 para evitar fitotoxidez.

Palavras-chave: fertilidade; Helianthus annuus L.; nutrição mineral; oleaginosa 


\section{Introduction}

The sunflower [Helianthus annuus L. (Asteraceae)] has prominent economic importance due to the quality of the fixed oil extracted from its seeds. Its oil is consumed all over the world, only behind the oils from soy [Glycine $\max$ (L.) Mer], palm (Elaeis guineenses Jacq) and rapeseed (Brassica napus L.) (Rauf et al., 2017). The sunflower cultivation meets the demand for inputs used in producing renewable energy when mixed with diesel, and besides that, the co-product generated from the oil extraction can be used for manufacturing feed for ruminant animals and fishes (Rodrigues \& Rondina, 2013; Castro \& Leite, 2018).

Brazil currently ranks in the twenty-sixth place in the world ranking and third in Latin America in the sunflower cultivation, having a planted area of 95.5 thousand hectares and a mean yield of $1578 \mathrm{~kg} \mathrm{ha}^{-1}$. The state of Mato Grosso is the largest sunflower producer in Brazil, followed by Goiás, with a production of 101.1 and 33.3 thousand tons respectively. Minas Gerais is the third largest producing state, with a production of 8.5 thousand tons (Conab, 2018).

In Northern Minas Gerais, sunflower is an alternative for agricultural cultivation in second-crop, as it adapts to the semi-arid climate. The plant has a deep root system, which making it possible to structure the soil and tolerate the water stress. Moreover, the plant also recycles nutrients and can have allelopathic effects on invasive plants, resulting in an increased income of small, medium and large producers (Ungaro, 2001; Oliveira et al., 2017).

The productive potential of sunflower genotypes depends on adopting management practices that favor their development, with the crop nutritional management standing out among these. The micronutrient Boron is essential for the sunflower development, since it takes part in the DNA synthesis and the pollen grain germination, in addition to forming the sugar/borate complex, contributing to the sugar translocation and protein formation (Gil-Martinez, 1995). On the other hand, the scarcity, lack and also the excess of boron in the sunflower fertilization can lead to nutritional problems such as damage to the meristem tissues and necrosis of leaf tissue and stems, affecting the photoassimilates production, the capitulum development and, consequently, causing production losses (Santos et al., 2010).

The absorption of nutrients by agricultural crops is determined by the interaction between the genetic load of plants and the environmental factors (Jardini et al., 2014) . There are interactions differences among genotypes of the same plant species, providing divergence in the nutrients absorption, which can reflect on the crops yield (Oliveira et al., 2009). Therefore, studying the boron absorption by sunflower genotypes is necessary since this nutrient is essential for the development of this plant, also with emphasis on the relevance of the interactions between genotypes and the environment. The objective of this study was to evaluate the agronomic performance of the sunflower genotypes BRS 321 and BRS 323, subjected to four boron fertilization doses and grown in Northern Minas Gerais.

\section{Materials and Methods}

The experiment was conducted in the field, in the experimental area of the Federal Institute of Northern Minas Gerais, Januária campus (located at $15^{\circ} 29^{\prime} \mathrm{S}, 44^{\circ} 21^{\prime} \mathrm{W}$ and at $434 \mathrm{~m}$ of altitude), from December 2015 to March 2016. The region climate is semi-arid, with a rainy season from November to March and a mean annual rainfall precipitation of $826.5 \mathrm{~mm}$ (Silva et al., 2017). Occurring climatic conditions during the experiment are displayed in the Table 1.

Chemical and physical soil analyzes performed presented the following results: $\mathrm{pH}=7.50 ; \mathrm{Ca}^{2+}=4.4 \mathrm{cmol}_{c} \mathrm{dm}^{-3} ; \mathrm{Mg}^{2+}=$ $0.6 \mathrm{cmol}_{c} \mathrm{dm}^{-3} ; \mathrm{Al}^{3+}=0.0 \mathrm{cmol}_{c} \mathrm{dm}^{-3} ; \mathrm{Al}^{3+}+\mathrm{H}=0.74 \mathrm{cmol}_{\mathrm{c}} \mathrm{dm}^{-3}$; $\mathrm{K}^{+}=142 \mathrm{mg} \mathrm{dm}^{-3} ; \mathrm{P}=32.2 \mathrm{mg} \mathrm{dm}^{-3} ; \mathrm{S}=0 \mathrm{mg} \mathrm{dm}^{-3} ; \mathrm{SB}=5.3 \mathrm{cmol}_{\mathrm{c}}$ $\mathrm{dm}^{-3} ; \mathrm{T}=6.1 \mathrm{cmol}_{\mathrm{c}} \mathrm{dm}^{-3} ; \mathrm{t}=5.3 \mathrm{cmol}_{\mathrm{c}} \mathrm{dm}^{-3} ;$ organic matter: 3 $\%$; sand $=67 \mathrm{dag} \mathrm{kg}^{-1}$; silt $=12 \mathrm{dag} \mathrm{kg}{ }^{-1}$; clay $=21 \mathrm{dag} \mathrm{kg}^{-1}$ and regarding the micronutrients: $\mathrm{Zn}=7.2 \mathrm{mg} \mathrm{dm}^{-3} ; \mathrm{Fe}=90 \mathrm{mg} \mathrm{dm}$. 3; $\mathrm{Mn}=71 \mathrm{mg} \mathrm{dm}^{-3} ; \mathrm{Cu}=0.0 \mathrm{mg} \mathrm{dm}^{-3}$ and $\mathrm{B}=0.1 \mathrm{mg} \mathrm{dm}^{-3}$.

The soil was prepared by plowing followed by harrowing. The furrows opening process was with a furrower regulated to the spacing of $0.7 \mathrm{~m}$ between rows. For fertilization, 20, 70 and $40 \mathrm{~kg} \mathrm{ha}^{-1}$ of $\mathrm{N}, \mathrm{P}_{2} \mathrm{O}_{5}$ and $\mathrm{K}_{2} \mathrm{O}$ were respectively applied (Ribeiro et al., 1999), alongside the respective boron (B) dose (boric acid), for each treatment. At 25 days after emergence of the sunflower, $40 \mathrm{~kg} \mathrm{ha}^{-1}$ of $\mathrm{N}$ were top-dressed (Ribeiro et al., 1999).

The design employed was randomized blocks, with four replicates and eight treatments in a $4 \times 2$ factorial scheme (boron dose $x$ sunflower genotypes). BRS 321 and BRS 323 were the genotypes used, both supplied by Embrapa Soybean. The used doses of $B$ were the following: 0 , which was the control; $1 \mathrm{~kg} \mathrm{ha}^{-1}$, as recommended by Ribeiro et al. (1999); $2 \mathrm{~kg} \mathrm{ha}^{-1}$, as recommended by Embrapa; and $4 \mathrm{~kg} \mathrm{ha}^{-1}$, due to the sandy aspect of the soil, which could favor its nutrient loss .

The sunflower planting was in plots of $10.08 \mathrm{~m}^{2}$, with four rows of $4.8 \mathrm{~m}$ each, in which the two central rows were considered as the useful plot area, with the borders ignored. Spacing used was of $0.7 \mathrm{~m}$ between rows and $0.3 \mathrm{~m}$ between pits, totaling 16 pits/row, with two seeds planted per pit and thinning held at seven days after germination, allowing the development of only one plant per pit.

The following variables were analyzed: plant height $(\mathrm{m})$, capitulum diameter $(\mathrm{cm})$, stem diameter $(\mathrm{mm})$, number of leaves (und), weight of 1000 achenes (g), grain yield $\left(\mathrm{kg} \mathrm{ha}^{-1}\right)$, fixed oil content (\%) and oil yield ( $\left.\mathrm{kg} \mathrm{ha}^{-1}\right)$

Table 1. Monthly means of the climate variables during the experimental period, Januária-MG.

\begin{tabular}{|c|c|c|c|c|}
\hline \multirow{2}{*}{$\begin{array}{c}\text { Month } \\
2016 / 2017\end{array}$} & Max. temp. & Min. temp. & \multirow{2}{*}{$\begin{array}{l}\text { Um. } \\
\text { (\%) }\end{array}$} & \multirow{2}{*}{$\begin{array}{l}\text { Precip } \\
(\mathrm{mm})\end{array}$} \\
\hline & \multicolumn{2}{|c|}{$\left({ }^{\circ} \mathrm{C}\right)$} & & \\
\hline December & 35 & 22 & 55 & 51.2 \\
\hline January & 31 & 22 & 82 & 456.5 \\
\hline February & 34 & 20 & 68 & 8.9 \\
\hline March & 33 & 21 & 69 & 74.8 \\
\hline
\end{tabular}

Source: INMET (2019). 
Plant height was obtained through the individual measurement of each plant in the useful area of the plot, from the soil to the capitulum insertion, at the early R1 stage. The capitulum diameter was determined by measuring the distance between the extremities of the capitulum, at the physiological maturation stage (R9). The stem diameter was determined by its measuring at $5 \mathrm{~cm}$ from the ground, with the aid of a digital caliper (Digimess brand, model 100.174bl), at the early R1 stage. The number of leaves was obtained by counting, in plants in the physiological maturation phase. For estimating the weight of 1000 achenes, the mean weight from 8 repetitions of 100 seeds was measured and multiplied by 10 . Yield was estimated by harvesting grains from the useful area of the plot and proportionally calculating it for one hectare. The oil content was estimated by means of organic solvent extraction, using $100 \mathrm{~mL}$ of hexane for three grams of crushed sunflower seeds, subsequently inserted in an oil and grease extractor (Marconi brand, model MA491/2) for 2 hours. The oil yield was considered from the relation between the grain yield and the oil content of the seeds.

The obtained data were subjected to the analysis of variance (ANOVA) and, when showing a significant difference, regression analysis was also performed. Variables that did not fit into any mathematical model were considered as the mean among treatments. Statistical analyzes were performed by using the program Sistema de Análise Estsatística (Statistical Analysis System) (UFV, 2007).

\section{Results and Discussion}

The highest plant height from the BRS 321 genotype was equal to the mean of the BRS 323 (Figure 1). It was significantly affected by the dose of B in the cultivar BRS 321, with a maximum estimated value of $1.74 \mathrm{~m}$ at the $0.58 \mathrm{~kg}$ $\mathrm{ha}^{-1}$ dose of B. In the BRS 323 genotype, no significant effect of fertilization with $B$ took place, with an estimated mean of $1.74 \mathrm{~m}$. The behavior difference between same-species genotypes, under similar cultivation conditions and from the same harvest, can provide a distinction in the absorption and accumulation of nutrients, resulting in variations in the agronomic characteristics, such as the height (Jardini et al., 2014). The BR 122 variety alongside with the Aguará and Gurupi hybrids demonstrated the highest heights found when $3 \mathrm{~kg} \mathrm{ha}^{-1}$ of B were provided (Capone et al., 2016), on the other hand, the varieties Hélio 863 and Leila did not obtain height gains from the doses of B (Euba Neto et al., 2014; Khalid et al., 2020).

The capitulum diameter of the BRS 323 genotype was greater at the $4 \mathrm{~kg} \mathrm{ha}^{-1}$ dose of $B(21.83 \mathrm{~cm})$, while for the BRS 321 genotype it was at the $2.68 \mathrm{~kg} \mathrm{ha}^{-1}$ dose $(20.62 \mathrm{~cm}$ ) (Figure 2 ). B increases the capitulum development of the sunflower, and deficiency of this element can cause reduction and deformations (Bonacin et al., 2008). However, the response to the $B$ increase can vary between genotypes; with the variety BR 122 and the hybrids Aguará and Gurupi having the largest capitulum diameter when nourished with $3 \mathrm{~kg} \mathrm{ha}^{-1}$ of $B$

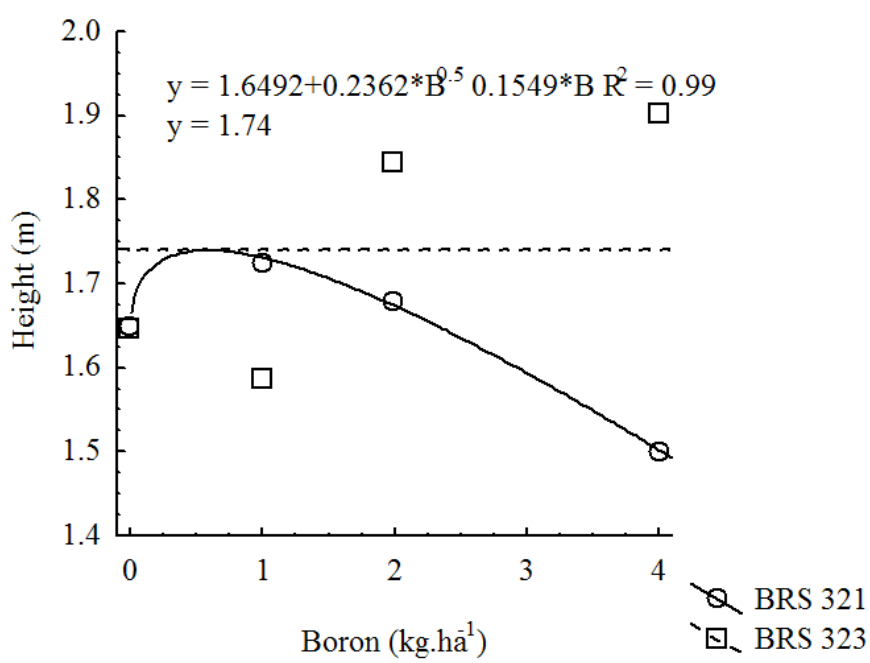

$* p<0.05$.

Figure 1. Height of the genotypes BRS 321 and BRS 323 in response to the boron doses, produced in Januária, Northern Minas Gerais.

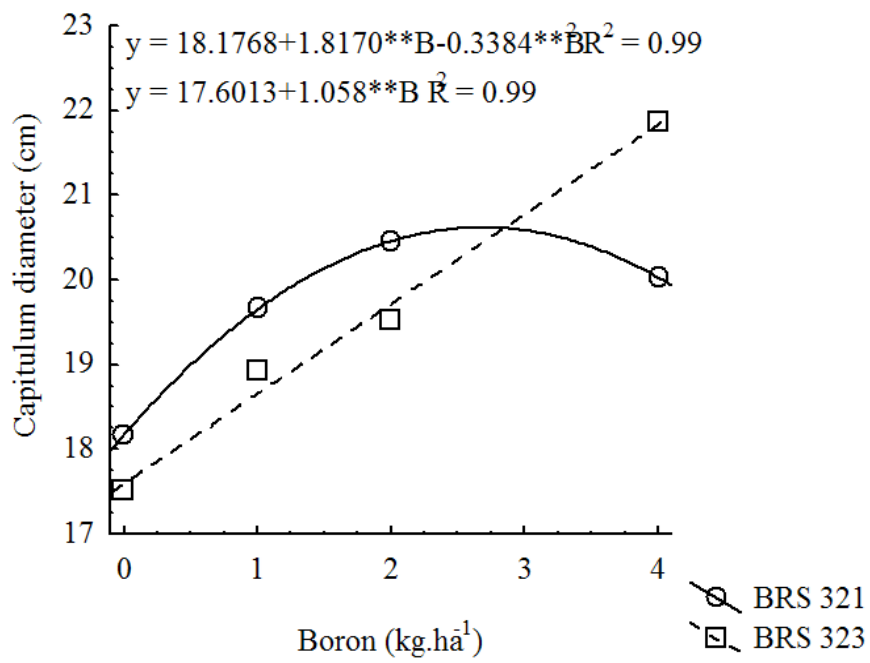

$* * 0.001<\mathrm{p}<0.01$.

Figure 2. Capitulum diameter of genotypes BRS 321 and BRS 323 in response to the boron doses, produced in Januária, Northern Minas Gerais.

(Capone et al., 2016), while in contrast, the varieties Embrapa 122/V-2000, Leila and Hélio 863 did not significantly respond to doses of B (Santos Junior et al., 2011; Euba Neto et al., 2014; Khalid et al., 2020).

No significant effect of the fertilization with $B$ occurred on the stem diameter of the BRS 323 genotype, with an estimated mean of $23.67 \mathrm{~mm}$, greater than the BRS 321 genotype, with the highest estimated value of $23.48 \mathrm{~mm}$ at the $0.52 \mathrm{~kg} \mathrm{ha}^{-1}$ dose of $B$ (Figure 3). B absorption by genotypes can be influenced by the interaction of plants with the environment, resulting in divergences in the response to the productive increases (Oliveira et al., 2009; Jardini et al., 2014). On the other hand, the reduction of the stem diameter with the increased $B$ dosage, may be related to the retention of micronutrient in the plant vegetative structures, compromising its metabolic function and redistribution (Lima et al., 2013). The Catissol 


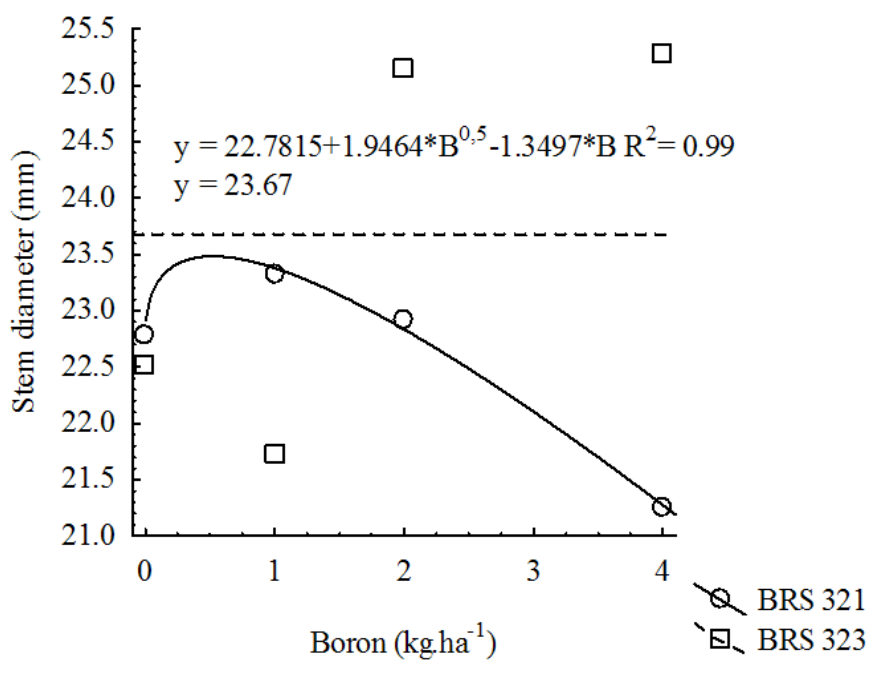

$* 0.01<\mathrm{p}<0.05$

Figure 3. Stem diameter of genotypes BRS 321 and BRS 323 in response to the boron doses, produced in Januária, nothern Minas Gerais.

variety had the largest stem diameter when subjected to $3 \mathrm{~kg}$ $\mathrm{ha}^{-1}$ of B (Lima, 2011); however, the varieties Embrapa 122/V2000 and Leila did not significantly respond to the doses of $B$ (Santos Junior et al., 2011; Khalid et al., 2020).

The largest number of leaves was from the BRS 321 genotype in comparison to the BRS 323 genotype (Figure 4). It was significantly affected by the doses of B in the BRS 321 genotype, with a maximum estimated value of 21.86 at the $0.77 \mathrm{~kg} \mathrm{ha}^{-1}$ dose. There was no significant effect on $B$ fertilization in the BRS 323 genotype, with an estimated mean of 20.5 leaves. Like the other vegetative variables, the number of leaves was influenced by B in the BRS 321 genotype, but there was no effect on BRS 323. The interaction between the plants genetic load and the environment factor determines the absorption of nutrients by agricultural crops (Jardini et al., 2014). Oliveira et al. (2009) state that there is a difference

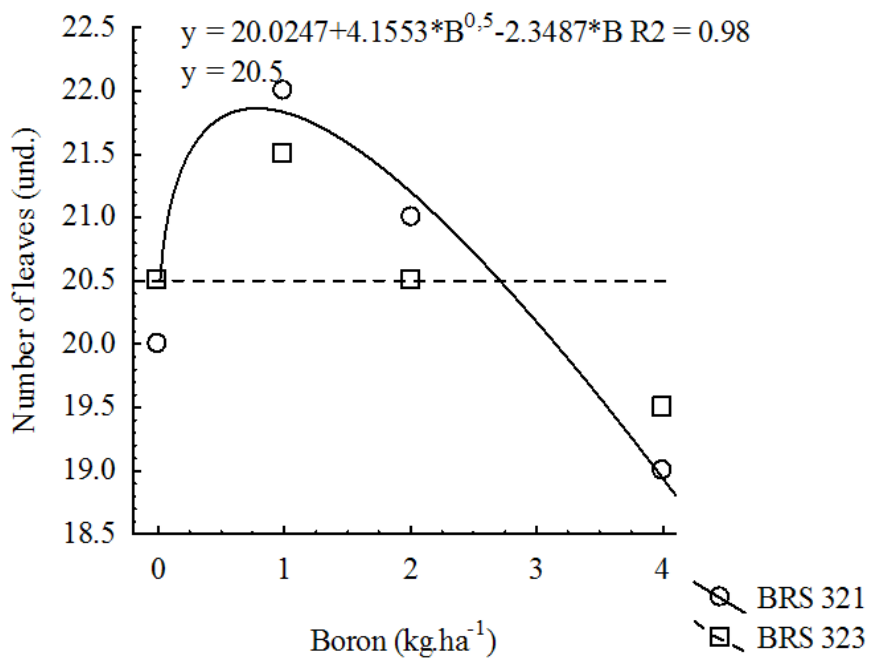

${ }^{*} 0.01<\mathrm{p}<0.05$

Figure 4. Number of leaves of genotypes BRS 321 and BRS 323 in response to the boron doses, produced in Januária, nothern Minas Gerais. in interactions among genotypes of the same species, causing divergence in the absorption of nutrients . Varieties Embrapa 122/V-2000 and Hélio 863 did not significantly respond to the boron doses regarding the number of leaves (Santos Junior et al., 2011; Euba Neto et al., 2014).

The lack of B micronutrient impairs the transport and action of growth reducers, which impedes the distribution of indolacetic acid and causes damage such as reduced protein synthesis and difficulties in forming the cell wall and transporting photoassimilates (Melo \& Lemos, 1991). Such activities compromise the vegetative growth of the sunflower, which explains the increased values of the vegetative variables with the fertilization with boron. Lower variables values due to fertilization with excess boron may be attributed to the Maximum Rule, in which the excess of a nutrient in the soil can promote a toxicological effect, triggering the difficulty in absorbing another element (Almeida et al., 2015). The high B content in the soil decreased the phosphorus content in peanut and spinach plants (Blamey \& Chapman, 1979). Omission of the phosphorus nutrient in the Catissol variety promoted a decrease in the number of leaves, plant height, stem diameter, and leaf area, in relation to the treatment which had the nutrient presence (Prado \& Leal, 2006).

The weight of 1000 achenes of BRS 321 was higher when compared to the BRS 323 genotype (Figure 5). This same variable had significant effects to the fertilization with boron in the BRS 321 genotype, with a maximum value estimated in $90.82 \mathrm{~g}$ at the $4 \mathrm{~kg} \mathrm{ha}^{-1}$ dose. The BRS 323 genotype did not demonstrate a significant response to the fertilization with boron, having an estimated mean of $83.41 \mathrm{~g}$. The BR 122 variety and the hybrids Aguará and Gurupi attained the largest weight of 1000 achenes when $3 \mathrm{~kg} \mathrm{ha}^{-1}$ of $\mathrm{B}$ were supplied (Capone et al., 2016). In contrast, the Leila variety did not obtain increased weight of 1000 achenes from the boron doses (Khalil et al., 2018).

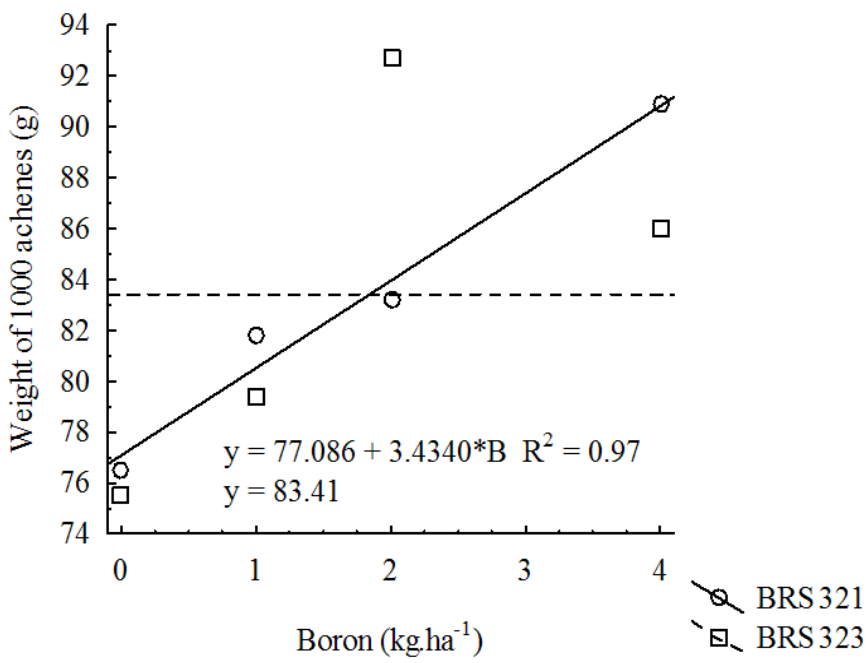

**0.001 $<\mathrm{p}<0.01$.

Figura 5. Weight of 1000 achenes of genotypes BRS 321 and BRS 323 in response to the boron doses, produced in Januária, nothern Minas Gerais. 
The highest yield was in the BRS 323 genotype when compared to the BRS 321 (Figure 6). It demonstrated significant effects to the fertilization with boron in the BRS 321 genotype, with a linear increase and an estimated value of $2276.37 \mathrm{~kg} \mathrm{ha}^{-1}$ at the $4 \mathrm{~kg} \mathrm{ha}^{-1}$ dose of B. The BRS 323 genotype did not show a significant response to the fertilization with boron, having an estimated mean of $2383.74 \mathrm{~kg} \mathrm{ha}^{-1}$. The Aditya variety had a better yield at the $2.32 \mathrm{~kg} \mathrm{ha}^{-1}$ dose of B (Bhattacharyya et al., 2015). The cultivar $M 734$, though, had the highest yield when submitted to $6.29 \mathrm{~kg} \mathrm{ha}^{-1}$ of B (Silva et al., 2016).

The oil content of the BRS 323 genotype was higher than the value of BRS 321 (Figure 7). It had a significant effect on the boron fertilization in the BRS 323 genotype, with a linear content increase and an estimated value of $50.61 \%$ at the 4 $\mathrm{kg} \mathrm{ha}^{-1}$ dose of boron. The BRS 321 genotype did not show significant response to fertilization with boron, having an

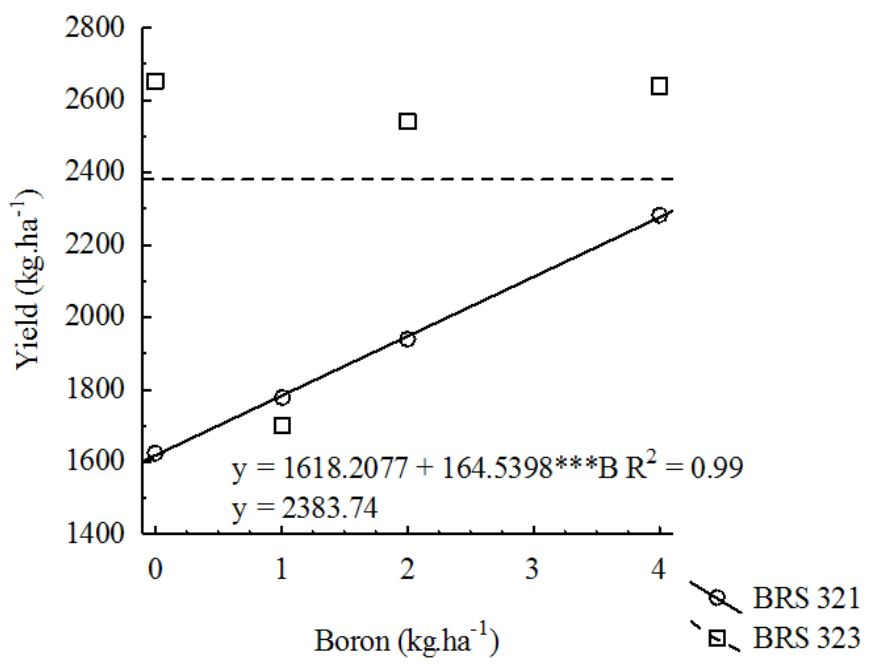

$* * * p<0,001$.

Figure 6. Yield of genotypes BRS 321 and BRS 323 in response to the boron doses, produced in Januária, nothern Minas Gerais.

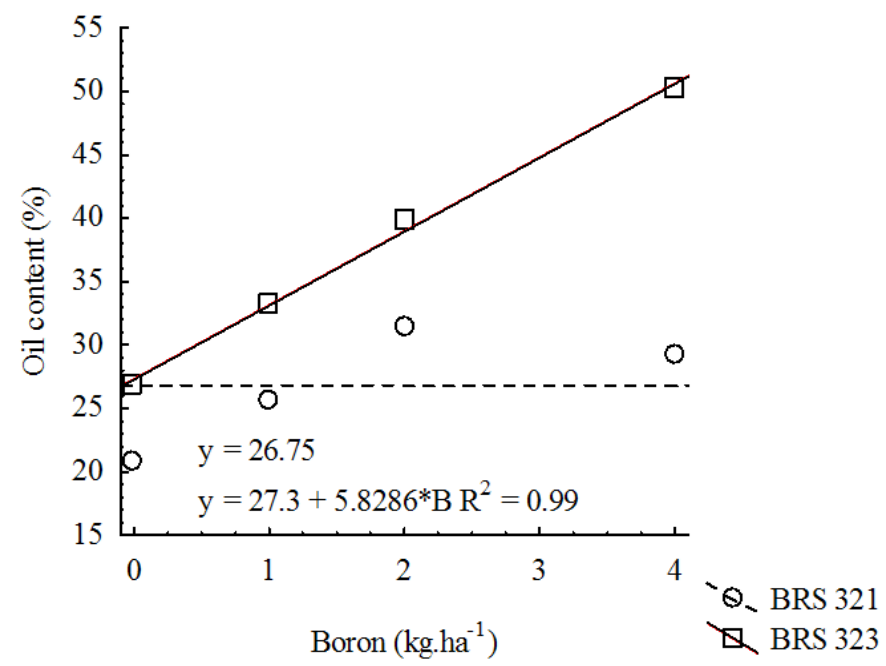

${ }^{*} 0.01<p<0.05$.

Figure 7. Oil content of genotypes BRS 321 and BRS 323 in response to the boron doses, produced in Januária, nothern Minas Gerais. estimated mean of $26.75 \%$. In an irrigated cultivation in the municipality of Nova Porteirinha-MG, the BRS 323 genotype yielded $42 \%$ oil by using $1 \mathrm{~kg} \mathrm{ha}^{-1}$ of boron (Resende et al., 2015).

The oil yield of the BRS 323 genotype was higher than the BRS 321 genotype (Figure 8). It had significant effects on the fertilization with B in the BRS 321 genotype, with a linear increase and an estimated value of $689.75 \mathrm{~kg} \mathrm{ha}^{-1}$ at the $4 \mathrm{~kg}$ $\mathrm{ha}^{-1}$ dose. The BRS 323 genotype did not obtain a significant response to the fertilization with $B$, with an estimated mean of $893.18 \mathrm{~kg} \mathrm{ha}^{-1}$. The BRS 323 genotype, in an irrigated cultivation in the municipality of Nova Porteirinha-MG, had an oil yield of $1207 \mathrm{~kg} \mathrm{ha}^{-1}$ by using $1 \mathrm{~kg} \mathrm{ha}^{-1}$ of B (Resende et al., 2015). On the other hand, the Catissol variety has a maximum oil yield of $1076.58 \mathrm{~kg} \mathrm{ha}^{-1}$ with the fertilization of $4 \mathrm{~kg} \mathrm{ha}^{-1}$ of B (Lima, 2011).

Both pollination and seed formation in vegetables are influenced by the $B$ presence, which may explain the variations in the weight of 1000 achenes, grain yield and oil content and yield in the genotypes evaluated in this study. B is essential in the germination of pollen grains, in the pollen tube growth and in the transport of sugar to the seeds (Lopes, 1989). The increased oil content and yield due to fertilization with $B$ was reported by Lima (2011) as resulting from the changes in the plant physiology.

The higher B dosages in this study, during the early development of the plant, caused a toxicity in the BRS 321 genotype, which then lead to an underdevelopment of the vegetative parts; however, the variables grain and oil yield had the highest values at the $4 \mathrm{~kg} \mathrm{ha}^{-1}$ dose of $\mathrm{B}$. This can be explained by the total fertilization with $B$ performed at the planting, which generated an initial toxicity. On the other hand, the leaching of $B$ due to the precipitation volume (Table $1)$, caused the reduction of the micronutrient content in the soil, which contributed to the plant reverting the toxicity condition. However, during the germination phase of the

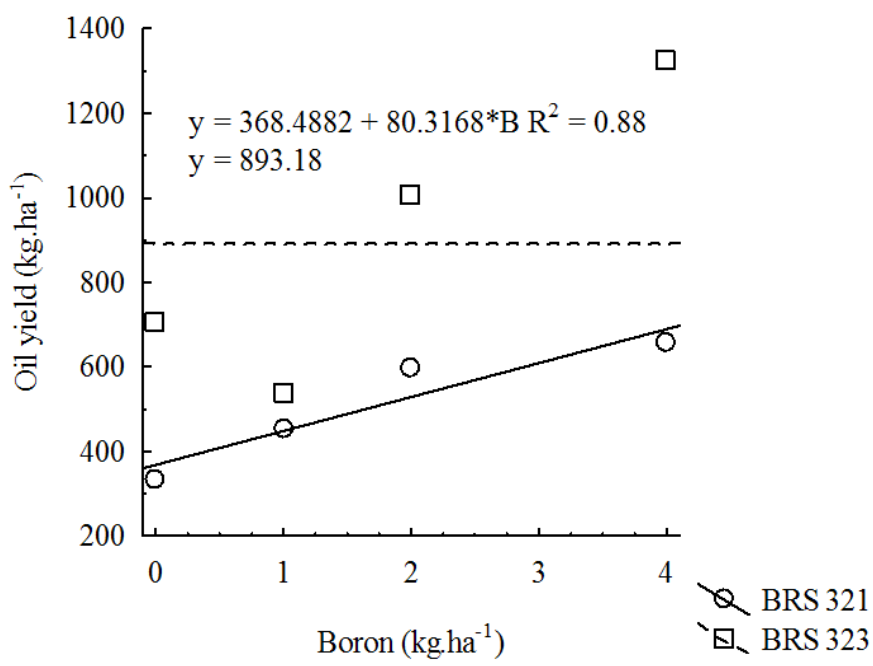

$* 0.01<p<0.05$.

Figure 8. Oil yield of genotypes BRS 321 and BRS 323 in response to the boron doses, produced in Januária, nothern Minas Gerais. 
pollen grain and the transport of sugar to the seed, the plants strongly require $B$, and the treatments with lower doses were impaired due to leaching of the micronutrient. Thereby, the treatments which had higher doses of $B$ had also a higher increase in their productive variables.

The responses to the $B$ doses from the genotypes BRS 321 and BRS 323 were different in the variables plant height, stem diameter, number of leaves, weight of 1000 achenes, grain yield and oil content and yield. This event can be explained by its genetic loads and the interaction between the genetic load of the plants and the environment factors determines the nutrients absorption by agricultural crops (Jardini et al., 2014). Furthermore, there is a difference in interactions among genotypes of the same species, causing divergence in the absorption of nutrients (Oliveira et al., 2009).

\section{Conclusions}

The best vegetative development responses in the BRS 321 genotype were attained with a dose lower than $1 \mathrm{~kg} \mathrm{ha}^{-1}$ of $\mathrm{B}$. The highest micronutrient values caused toxicity to this genotype.

The highest oil and grain yield of the BRS 321 genotype was attained with the supply of $4 \mathrm{~kg} \mathrm{ha}^{-1}$ of $\mathrm{B}$.

The doses of B in the BRS 323 genotype did not influence the vegetative variables, however, the oil content was higher when supplying $4 \mathrm{~kg} \mathrm{ha}^{-1}$. The BRS 323 genotype, had increased grain and oil yield regardless of $B$ doses, thus being superior to BRS 321.

\section{Acknowledgements}

To the "Brazilian National Council for Scientific and Technological Development (CNPq)", "Coordination for the Improvement of Higher Education Personnel (CAPES)" and "Minas Gerais State Research Foundation (FAPEMIG)" for the financial support. The "Brazilian Agricultural Research Corporation (Embrapa)" for granting the used seeds.

\section{Literature Cited}

Almeida, A. E. S.; Bezerra Neto, F.; Costa, L. R.; Silva, M. L.; Lima, J. S. S.; Barros Junior, A. P. Eficiência agronômica do consórcio alface-rúcula fertilizando com flor de seda. Revista Caatinga, v. 28 , n. 3, p. 79-85, 2015. https://doi.org/10.1590/198321252015v28n309rc.

Bhattacharyya, K.; Mandal, J.; Banerjee, H., Alipatra, A.; Ray, K.; Phonglosa, A. Boron fertilization in sunflower (Helianthus annuus L.) in an inceptisol of West Bengal, India. Communications in Soil Science and Plant Analysis, v. 46, n. 4, p. 528-544, 2015. https:// doi.org/10.1080/00103624.2014.997389.

Blamey, P. P. C.; Chapman, J. Boron toxicity in Spanish groundnuts. Agrochemophysica, v.11, n.4, p. 57-59, 1979. https:// journals.co.za/content/agro/11/4/AJA03027112_495. 26 Dez. 2018.
Bonacin, G. A.; Rodrigues, T. D. J.; Cruz, M. C.; Banzatto, D. A. Características morfofisiológicas de sementes e produção de girassol em função de boro no solo. Revista Brasileira de Engenharia Agrícola e Ambiental, v. 13, n. 02, p. 111-116, 2008. https://doi.org/10.1590/S1415-43662009000200001.

Capone, A; Dario, A. S.; Menegon, M. Z.; Fidelis, R. R.; Barros, H. B. Respostas de cultivares de girassol a doses crescentes de boro na entressafra do Cerrado Tocantinense. Revista Verde, v.11, n.1, p.43-48, 2016. https://doi.org/10.18378/rvads.v11i1.4004.

Castro, C.; Leite, R. M. V. B. C. Main aspects of sunflower production in Brazil. Oilseeds and fats. Crops and Lipids, v. 25, n. 1, p. 104115, 2018. https://doi.org/10.1051/ocl/2017056.

Companhia Nacional de Abastecimento - Conab. Acompanhamento da safra brasileira de grãos. Brasília: Conab; 2018. 148p. (v.5 safra 2017/2018, n.11, décimo primeiro levantamento). https:// www.conab.gov.br/info-agro/safras/graos/boletim-da-safra-degraos/item/download/21709_4d6f8550138ed03890d0bba9f9 db1675 10 Dez. 2019.

Euba Neto, M.; Fraga, V. S.; Dias, B. O.; Souto, J. S. Efeito de doses de boro no crescimento vegetativo de girassol em diferentes classes de solos. Revista Ceres, v.61, n.3, p.399-405, 2014. https://doi. org/10.1590/S0034-737X2014000300015.

Gil-Martinez, F. Elementos de fisiologia vegetal: relaciones hídricas, nutrición mineral, transporte, metabolismo. Madrid: Ediciones Mundi-Prensa, 1995. cap. 7, p. 249-283.

Instituto Nacional de Meteorologia - INMET. Estações e dados. http://www.inmet.gov.br/portal/index.php?r=estacoes/ estacoesAutomaticas. 03 Jan. 2019.

Jardini, D. C.; Scaramuz, W. L. M. P.; Weber, O. L. S.; Borba Filho, A. B.; Fernandes, D. Á. Absorção de nutrientes em genótipos de girassol. Pesquisa Agropecuária Tropical, v.44, n.4, p.434-442, 2014. https://doi.org/10.1590/S1983-40632014000400011.

Khalid, D.; Saad, D.; Kacem, M.; Ezzahra, N. F.; Fouad, A.; Abdelhadi, A. $\mathrm{H}$. Sunflower response to Boron supply when grown in a silty clay soil. Journal of the Saudi Society of Agricultural Sciences, v.19, n.1, p.81-86,2020. https://doi.org/10.1016/j.jssas.2018.06.004.

Lima, A. D.; Viana, T. V. A.; Azevedo, B. M.; Marinho, A. B.; Duarte, J. M. L. Adubação borácica na cultura do girassol. Revista Agro@mbiente On-line, v. 7, n. 3, p. 269-276, 2013. https://doi. org/10.18227/1982-8470ragro.v7i3.1237.

Lima, A.D. Interações entre lâminas de irrigação e coberturas do solo, e adubação borácica na cultura do girassol. Fortaleza: Universidade Federal do Ceará, 2011. 72p. Dissertação Mestrado.

Lopes, A. S. Manual de fertilidade do solo. São Paulo: ANDA/ POTAFÓS, 1989. 153 p.

Melo, J.W.; Lemos, E.G.M. Análise bioquímica de plantas. In: Simpósio sobre Micronutrientes na Agricultura, 1., 1988, Jaboticabal. Anais... Piracicaba: POTAFOS/CNPq, 1991. p.310-331.

Oliveira, A. R. D.; Oliveira, S. A. D.; Giordano, L. D. B.; Goedert, W. J. Absorção de nutrientes e resposta à adubação em linhagens de tomateiro. Horticultura Brasileira, v. 27, n. 4, p. 498-504, 2009. https://doi.org/10.1590/S0102-05362009000400016.

Oliveira, S. L.; Gomes Filho, A.; Soares, D. P.; de Souza, T. A. N.; Leandro, R. I.; Rodrigues, E. N. Desempenho agronômico de genótipos de girassol cultivados sob déficit hídrico no semiárido Mineiro. Acta Iguazu, v.6, n.4, p.93-104, 2017. http://e-revista. unioeste.br/index.php/actaiguazu/article/view/16438/12112 19 Jan. 2019. 
Prado, R. M.; Leal, R. M. Desordens nutricionais por deficiência em girassol var. Catissol-01. Pesquisa Agropecuária Tropical, v.36, n.3, p.187-193, 2006. https://www.revistas.ufg.br/pat/article/ view/2046. 17 Jan. 2019.

Rauf, S.; Jamil, N.; Tariq, S.A.; Khan, M; Kausar, M.; Kaya, Y. Progress in modification of sunflower oil to expand its industrial value. Journal of the Science of Food and Agriculture, v.97, n.7, p.19972006, 2017. https://doi.org/10.1002/jsfa.8214.

Ribeiro, A. C.; Guimarães, P. T. G.; Alvarez, V. H. Recomendações para uso de corretivos e fertilizantes em Minas Gerais: $5^{a}$ aproximação. Belo Horizonte: Comissão de Fertilidade do Solo do Estado de Minas Gerais, 1999. 310p.

Rodrigues, F. V.; Rondina, D. Alternativas de uso de subprodutos da cadeia do biodiesel na alimentação de ruminantes: glicerina bruta. Acta Veterinaria Brasilica, v. 7, n. 2, p. 91-99, 2013. https:// rbmv.org/index.php/acta/article/view/2801. 17 Jan. 2019.

Santos Junior, J. A.; Gheyi, H. R.; Dias, N. S.; Soares, F. A. L.; Nobre, R. G. Doses de boro e água residuária na produção do girassol. Revista Ciência Agronômica, v.42, n.4, p.857-864, 2011. https://doi. org/10.1590/S1806-66902011000400006.
Santos, L. D.; Melo, F. D.; Souza, U. O.; Primo, D. C.; Santos, A. D. Fósforo e boro na produção de grãos e óleo no girassol. Enciclopédia Biosfera, v. 6, n. 11, p. 1-8, 2010. https://www. researchgate.net/publication/256078990. 21 Out. 2019.

Silva, F. D. B.; Aquino, L. A.; Panozzo, L. E.; Lima, T. C.; Berger, P. G.; Dias, D. C. F. D. S. Influence of boron on sunflower yield and nutritional status. Communications in Soil Science and Plant Analysis, v. 47, n. 7, p. 809-817, 2016. https://doi.org/10.1080/00103624.2016.1146894.

Silva, M. R.; Moura, F. P.; Jardim, C. H. O diagrama de Caixa (Box Plot) Aplicado à Análise da Distribuição Temporal das Chuvas em Januária, Belo Horizonte e Sete Lagoas, Minas GeraisBrasil. Revista Brasileira de Geografia Física, v. 10, n. 1, p. $023-$ 040, 2017. http://www.revista.ufpe.br/rbgfe/index.php/revista/ article/view/1869/1129. 27 Dez. 2019.

Ungaro, M. R. G. Mercados potenciais para o girassol e os seus subprodutos. In: Câmara, G. M. S.; Chiavegato, E. J. (Eds.). O agronegócio das plantas oleaginosas: algodão, amendoim, girassol e mamona. Piracicaba: ESALQ, 2001. p. 123-140.

Universidade Federal de Viçosa - UFV. Sistema para análises estatísticas - SAEG, versão 9.1. Viçosa: UFV, 2007. 